\title{
SOCIAL PSYCHOLOGY
}

\section{Migration as an indicator of people's social and psychological stability (as exemplified in the Pskov Region)}

\author{
Svetlana D. Gurieva* ${ }^{*}$ Svetlana N. Kostromina, Larisa A.Tcvetkova, \\ Irina A. Samuylova, Aleksandr G. Konfisakhor, Tatyana V. Anisimova
}

Saint Petersburg State University, Saint Petersburg, Russia

*Corresponding author. E-mail: gurievasv@gmail.com

Years of social, economic, and political changes have resulted in intensive and extensive migration activity. The appearance of compelled and voluntary migrants has brought about the development of a new direction in social psychology: the psychology of migration. Many disciplines are connected with the study of migration, the problems of migrants, and adaptation processes. In the social-psychological literature, various models of adaptation to new conditions of a social-cultural environment are considered (I. Jasinskaja-Lahti, K. Liebkind, J. Berry; S.-K. Lee, J. Sobal, E. Frongillo). Various social-psychological features of migrants are studied: for example, ethnic identity, characteristics of psychological adaptation, emotional well-being, and mental health. In the Russian scientific literature the following problems are considered: emigrants' interactions with representatives of foreign cultures (N. S. Khrustaleva), degree of cultural similarity (T.G. Stefanenko), personal features of emigrants (S. H. Schwartz, E. Prince-Gibson), features of ethnic identity (G.U. Soldatova, S. D. Gurieva), and many others. In Russia, research regarding the influence of the social-cultural environment on processes of adaptation were begun only in 2004 .

The main objective of our study was to identify psychological mechanisms of migration flows (incoming and outgoing) as indicators of sociopolitical and psychological stability in the Pskov Region. Participants in the study were citizens permanently residing in the Pskov Region who by age and social characteristics represented the population structure of a part of that region. In total, 52 persons aged 17 to 69, with an average age of 42.3 , participated.

The technique used was focus groups. A content analysis was made of the answers received in the focus-group sessions. During these sessions, participants could freely share their views on questions asked by the facilitators who had a college-level psychological education. In each group, two facilitators worked cooperatively. One facilitator was in charge of group dynamics; the other was in charge of asking all the questions covered as well as of keeping track of all the substantial aspects of the conversation. This arrangement encouraged the participants to discuss issues of the region in an open manner. 
The findings allowed us to classify all the migrants and potential migrants in the Pskov Region according to their reasons and motives for migration. For example, in the Plyussa settlement, which is "depressed" and remote from the region's center, migrants seek to escape their extreme poverty and unemployment; they can be called "survival migrants." In the "favored" central area, the city of Pskov, migrants seek to significantly increase their income level and improve their quality of life. We can describe them as "migrants seeking new opportunities." In a border area, the town of Gdov, people living in close proximity to other countries (Estonia, Latvia) compare their financial situation and opportunities with those of their foreign neighbors. Migrants living in Gdov tend to move because they want to avoid an environmental crisis or progressive degradation of the environment, structural unemployment, and poor economic opportunities. We can call them "migrants in search of hope and prosperity."

In the Pskov Region, the labor (economic) situation is a typical reason for migration. Migration for economic reasons is a resettlement of people for the purpose of employment and proper remuneration. Labor migration can have such causes as a desire to change one's job, as well as sociocultural, housing, environmental, nature, climate, and other conditions. Without a developed economy and social sphere, regions are able to prevent only elderly or incapacitated people from migrating. To retain the younger generation, it is necessary to inform people of all the possible difficulties that potential migrants may face and to make systematic and large-scale efforts to develop the region, to improve the image of the region (including encouraging the residents to be proud of and to cherish the region's heritage and its people's achievements), and to create a comfortable environment.

Keywords: migration processes, reasons for migration, potential migrants, the Pskov Region.

\section{Introduction}

Migration continues to be one of the most pressing and difficult issues in global society and in Russian society in particular. Places of military, political, and economic instability face economic problems, the destruction of a traditional way of life, growing tensions, and people's uncertainty in regard to the future. All these factors facilitate the growth of migration flows.

The academic corpus of literature contains numerous works on migration. The first academic definition of migration was given by Ravenstein (1985, p. 168).

[Migration is] a permanent or a temporary change of place of residence by a person; [this is] a continuous process depending on the interactions among four main groups of factors. They are factors that influence a migrant's initial place (country) of residence; factors that influence the stage of a migrant's move; factors that influence a migrant's destination (country); factors of a personal nature, which include, primarily, a system of personal preferences, a totality of personal demographic characteristics.

Most articles about migration refer to the acculturation of migrants and acculturation modeling (Berry, 1992; Khrustaleva, 1996; Gurieva, Kinunen, 2006; Pavlenko, 2001); the ethnic identity of migrants (Gurieva \& Kinunen, 2006; Lebedeva, 2001; Pavlenko, 2001; Stefanenko, 1999); the dynamics of migration and adaptation issues (Belinskaya \& Stefanenko, 2000; Hutnik \& Barrett, 2003; Jasinskaja-Lahti, 2000; Schwartz, 1992), along with many other aspects of migration. However, there 
are significantly fewer articles on the psychology of potential migrants (Gurieva \&Kinunen, 2010; Liebkind, 2001; Mirsky, 2001; Tartakovsky, 2007; Zilber \& Lerner, 1996). There are no social, psychological, or sociological articles that compare different types of potential and actual migrants or forced and voluntary migrants or that identify migrants' common and specific characteristics depending on the environment of their place of residence in a single administrative entity within the boundaries of the single environment of the Russian Federation.

In today's ever-changing Russian society, there have been changes not only in the types and direction of migration but also in the characteristics of the migration processes: conditions and types of migration, social and psychological characteristics of migrants, factors determining their successful adaptation and acculturation, their motivation, their features, and many other social, demographic, and psychological characteristics. Therefore, the issues that have been researched are not the kinds of migration, their stages and types, for example, but, instead, the main causes of migration. For example, ethnic migration is known to be a consequence of interethnic conflicts, ethnic tensions, ethnic discrimination, and lost social and cultural identity by a certain part of the population. Labor migration can be a consequence of a deep economic crisis, social and economic instability, lost jobs, and increasing poverty and unemployment within a complex political situation in general.

Migration can take two forms: forced and voluntary. The most difficult for regulation are forced forms, as they have a spontaneous and massive character; they transform the existing structure of the society. Voluntary migration is generally the more regulated process. It is neither massive, nor natural; it is partially distributed in time. With voluntary migration, structural components of the society survive instead of being transformed (Table 1).

Table 1. Natural and forced migration

\begin{tabular}{|c|c|c|c|c|c|}
\hline \multicolumn{3}{|c|}{ Natural } & \multicolumn{3}{|c|}{ Forced } \\
\hline \multicolumn{3}{|c|}{$\begin{array}{l}\text { Migration is partly regulated, } \\
\text { time-distributed }\end{array}$} & \multicolumn{3}{|c|}{$\begin{array}{l}\text { Migration has explosive, } \\
\text { burst-type character }\end{array}$} \\
\hline \multicolumn{3}{|c|}{$\begin{array}{l}\text { Structural components of the society } \\
\text { survive }\end{array}$} & \multicolumn{3}{|c|}{$\begin{array}{l}\text { Structural components of the society are } \\
\text { transformed }\end{array}$} \\
\hline $\begin{array}{l}\text { Migrants are } \\
\text { professionals }\end{array}$ & $\begin{array}{l}\text { Migrants are } \\
\text { adaptive }\end{array}$ & $\begin{array}{l}\text { Migrants are } \\
\text { independent }\end{array}$ & $\begin{array}{l}\text { Migrants go } \\
\text { through depro- } \\
\text { fessionalization }\end{array}$ & $\begin{array}{l}\text { Migrants are } \\
\text { nonadaptive }\end{array}$ & $\begin{array}{l}\text { Migrants are } \\
\text { dependent }\end{array}$ \\
\hline
\end{tabular}

In the academic corpus, as part of the research on migrants' motivation, the theory of "push and pull" (push/pull factors) has appeared; this theory was proposed by Lee (1966, pp. 47-57). It explains the main cause for migration as a combination of push factors, which encourage people to leave their places of origin, and pull factors, which are attractive to people in other regions. The push factors include high prices, a low living standard, poor economic opportunities, political repression, and structural unemployment at the place of departure. The push factors may also include a threat to the life or health of potential migrants or family members and psychological dissatisfaction. The pull factors include a demand for labor, employ- 
ment opportunities, broad economic opportunities and high wages rates, political freedom, safety, psychological well-being, and a comfortable environment.

Depending on where one moves to, migration is internal or external. The simplest definition of these types of migration is the following. Internal migration is the movement of people within their area or their region, or movement to a new location within the same country. External migration is movement outside one's country. Population migration is the clearest and most accurate indicator in today's society of the socioeconomic well-being, political sustainability, and sociocultural attractiveness of a region, province, or country in general. As Berger and Luckmann (1966) said, migrants are people who actively construct social reality for themselves and others (1966, p. 194-195). "Tracking beliefs, evaluations and intentions of people, influencing them, and then adjusting (according to results) a strategy for one's actions, one may secure sustainable development" (Zakharov, Voronin \& Zakharov, 2014, p. 26).

\section{Method}

\section{Background}

Today, an important and indispensable element of the stabilization and further development of any country, any region, any city, or any area implies not only an available, strategically-oriented program aimed at improvements in the quality of people's lives but also an opportunity to implement this program in the lives of real people. For this very reason, we need not only to consider psychological criteria but also to have a deep understanding of ongoing socioeconomic, sociopolitical, and cultural changes and transformations. In Russia today, as exemplified by the Pskov Region, authorities have implemented the Strategy for Social and Economic Development. This strategy is aimed at understanding ongoing social changes, including migration changes.

The demography of the Pskov Region has been among the most unfavorable of all Russian regions. Manakov and Krivulya (2012, p. 76) list three main reasons for the current situation in the Pskov Region.

Firstly, for the last two decades, the Region has been an undisputed national leader in terms of population mortality and natural wastage indicators. Secondly, since it received its borders, the Pskov Region has only lost population. Thirdly, in 1966 the Pskov Region became the first Russian region where the death rate exceeded the birth rate, i.e., a quarter of a century earlier than in the country as a whole.

Compared with other regions in the Russian Federation, the Pskov Region is ranked below average in quality of life. The region ranks 59 out of 83 in the ratio of the average wage to the cost of a fixed consumer basket. Typical wages are low; there is almost no high-income population (less than 1 per cent). Transport to other cities is accessible via four major highways and five rail routes. Pskov Region shares three external borders with neighboring countries and four internal borders with other regions (Rosstat, 2013).

Given its specific location and socioeconomic segmentation (three specific areas: border, central, and remote), Pskov Region is a major platform for understand- 
ing the social and psychological processes that take place against the background of socioeconomic changes. In addition, the underlying problems of the socioeconomic development of the region are typical for many Russian regions (Evdokimov, 2010): depopulation because of high rates of migration;, a large portion of the population above the working age; a low standard of living; a low level of economic development; poor fiscal capacity; concentration of the economic and social activities of the population mainly around key support centers (the cities of Pskov and Velikie Luki), with a developed system of towns and settlements in place.

For the purpose of discussion, we have isolated three areas in the Pskov Region based on an analysis of its unique location, its remoteness from large cities, its three adjacent outer borders, its major highways, its growth in migration outflow and inflow, and its ratio of residents to visiting population. The three areas we have identified are: depressed, border, and favorable. Names for the areas are given for the purpose of discussion and depend on the influence of the following factors: level of migration flow (both external and internal); uniform or nonuniform distribution of the population within the region; location of administrative, medical, educational, and other facilities; their distance from settlements; available cultural, shopping, entertainment, and central industrial facilities.

For example, for a depressed area/district (in particular, Plyussa settlement) the following features may be typical: a low fertility rate, a high mortality rate, an excess of deaths over births, a high level of outmigration, an unbalanced workforce, a negative migration balance, a high elder (aging) population, undeveloped (neglected) infrastructure, not enough road networks, a high unemployment rate, alcoholism.

At the same time, for the border municipalities (like the town of Gdov) the following features are typical: a continuing increase in the birth rate; a high level of intermarriage and, possibly, of divorce; simultaneous mixing of two streams: a migratory outflow of the local population (with prevailing sporadic, seasonal migration) and a migratory inflow of visiting people from other Russian regions, the CIS and non-CIS countries, Central Asia (Uzbekistan, Tajikistan, Kazakhstan), China, Vietnam. The migration balance is positive, perhaps because of migration from Central Asia. For border areas, typical factors are the increasing socioeconomic differentiation of the society, unequal distribution of wages between employed locals and visitors (higher wages for army personnel compared with those for civilians, an opportunity for those in the military to get more qualified medical assistance), unequally distributed social benefits.

Finally, for favorable municipal areas (like the city of Pskov) the following features are typical: an increase in the birth rate, high population growth, many economic and cultural centers (shopping, entertainment, sports), a high and stable level of income, a number of people with a college education, a relatively low unemployment rate, stabilization of migration outflow, regulated migration inflow, wage rates and social benefits that are relatively high for the region.

\section{Purpose}

Our research looked at the current state of migration processes in the Pskov Region in order to understand the true state of the issue and to identify the main causes for migration. A main objective was to identify psychological mechanisms in migration flows (incoming and outgoing) as indicators of the sociopolitical and 
psychological stability of the region. In addition, the opportunity to control migration flows contributes to reasonable and appropriate managerial decisions aimed at successful implementation of the Concept of Socioeconomic Development of the Pskov Region through 2020. It should be noted that the Concept of Socioeconomic Development of the Pskov Region is one of the main directions of development the various regions of modern Russia.

\section{Participants}

Participants in the study were citizens permanently residing in the Pskov Region who by age and social characteristics represent the population structure of the part of the region under consideration. In total, 52 persons aged 17 to 69 participated; their average age of 42.3 .

\section{Subject of research}

The research solicited the views of the participants, their ideas and philosophy (conscious and unconscious), judgments and opinions on migration issues in the Pskov Region.

Table 2. Key questions

\begin{tabular}{|c|c|c|c|}
\hline $\mathbf{N}$ & Question & Purpose of question & Possible directions for answers \\
\hline 1. & $\begin{array}{l}\text { Which statement do } \\
\text { you most agree with? } \\
\text { Everyone has a right } \\
\text { to live where (s)he } \\
\text { wants. } \\
\text { You get worn out in } \\
\text { the place where you } \\
\text { were born. }\end{array}$ & $\begin{array}{l}\text { Identify prevailing migra- } \\
\text { tion philosophy in society, } \\
\text { number of actual and po- } \\
\text { tential migrants }\end{array}$ & $\begin{array}{l}\text { Attitude to those who have left, at- } \\
\text { titude to those who are going to leave, } \\
\text { own plans regarding migration (or } \\
\text { lack of them), willingness to move } \\
\text { and relocate, preferred migration } \\
\text { destinations }\end{array}$ \\
\hline & $\begin{array}{l}\text { Why do you think } \\
\text { people migrate? }\end{array}$ & $\begin{array}{l}\text { Identify major causes for } \\
\text { migration; determine } \\
\text { which of three main mo- } \\
\text { tives for migration prevails: } \\
\text { survival, self-development, } \\
\text { materialism }\end{array}$ & $\begin{array}{l}\text { Personal safety and well-being; } \\
\text { opportunities for development, } \\
\text { training, career; financial security; } \\
\text { improved quality of life; opportunity } \\
\text { to earn more }\end{array}$ \\
\hline & $\begin{array}{l}\text { For what reasons } \\
\text { would you leave } \\
\text { the Pskov Region? } \\
\text { Where would you } \\
\text { go? }\end{array}$ & $\begin{array}{l}\text { Identify push factors cont- } \\
\text { ributing to a growth of } \\
\text { migration in the region; } \\
\text { indicate the most preferred } \\
\text { destinations for migration } \\
\text { from the region }\end{array}$ & $\begin{array}{l}\text { Financial well-being, opportunities } \\
\text { for self-development and children's } \\
\text { development, increase level of edu- } \\
\text { cation, psychological satisfaction, } \\
\text { ecology }\end{array}$ \\
\hline & $\begin{array}{l}\text { What attracts you to } \\
\text { other regions, cities? }\end{array}$ & $\begin{array}{l}\text { Identify factors of attrac- } \\
\text { tion to other regions that } \\
\text { encourage migration from } \\
\text { the Pskov Region }\end{array}$ & $\begin{array}{l}\text { Demand for workforce, high stan- } \\
\text { dard of living, economic opportuni- } \\
\text { ties, social benefits, cultural life and } \\
\text { leisure activities, a right to freedom of } \\
\text { movement }\end{array}$ \\
\hline 5. & $\begin{array}{l}\text { What could prevent } \\
\text { you from leaving the } \\
\text { Pskov Region? }\end{array}$ & $\begin{array}{l}\text { Identify factors that cause } \\
\text { people to stay at a given } \\
\text { time and in the long term }\end{array}$ & $\begin{array}{l}\text { Hope for possible changes in the } \\
\text { region in the future, understanding } \\
\text { of the difficulties and troubles related } \\
\text { to migration; patriotism and love of } \\
\text { homeland, of one's own territory, area }\end{array}$ \\
\hline
\end{tabular}




\section{Methods}

Participants views on migration issues were collected in focus groupss. A content analysis was made of answers given in the focus-group sessions. In these sessions, participants could freely share their views on questions asked by the facilitators, who had a psychological education at the college level. In each group, two facilitators worked cooperatively. One facilitator was in charge of the group dynamics; the other was in charge of covering all questions as well as of keeping track of all substantial aspects of the conversation. The psychological atmosphere in the focus-group sessions was comfortable. It encouraged the participants to discuss issues in an open manner. It did not prevent them from spontaneous (true, unconscious) behavioral responses that demonstrated true emotions, feelings, and moods. Five questions were asked with recommended directions for answers to them (Table 2).

\section{Results}

The ideas of respondents from a border area were gleaned from residents of the town of Gdov. Gdov (like other border towns in the Pskov Region) has typical kinds of migration, such as labor migration and commuting migration (regular transfers of the population between two or more areas without a change in their place of residence for reasons of employment, training, or vacation). In this border area, the main reasons for people to migrate and leave their homes are unemployment and a wage rate below the subsistence level (because of the destruction of infrastructure and the devastation of farms and industrial complexes that once existed in the area. People have nothing to do, nowhere to go (no cultural, sports, shopping, or entertainment facilities), and poor transportation to other areas (which leads to a sense of social and psychological isolation, a sense of abandonment). In line with the well-known theory in the scientific literature regarding push and pull factors, the push factors include a low standard of living, poor economic opportunities, structural unemployment, and psychological dissatisfaction. The pull factors are the better economy in attractive nearby foreign countries (Estonia and Latvia, with which the Pskov Region has borders) and the psychological similarity of these areas.

However, there are also constraining factors. The question "What could prevent you from leaving the Pskov Region?" engendered the following answers: no money for relocation, no housing at destination, expensive mortgage, lack of desire to live worse than at home. In other words, people listed mainly economic factors. However, the most meaningful and important for us are sociocultural associations related to one's area. A content analysis of the most frequently mentioned associations identified cognitive and emotional components of images of one's own culture. The cognitive component included the following groups of associations: the Chudskoy lake, forests, the climate, people, hunting. The emotional component enhances the importance of cultural symbols by giving them a positive sensation: the famous lake, beautiful nature, rich forests, good climate, wonderful people (welcoming, responsive, sincere, kind, and open).

The ideas of respondents from a central, "favorable" area were gleaned from residents of the city of Pskov. Migration in the city is typically seasonal or irrevo- 
cable. Seasonal (temporary) migrations include regular trips to another place of residence, often in nearby metropolitan centers. Irrevocable migration is migration with no intention to return to the place of origin; the final objective is to gain a foothold and make one's way in life at the destination.

Reasons for people in the city of Pskov to leave their homes include a low living standard; parents' low wages, which mean limited prospects for youth; a lack of prospects for future development; a media-made image of "successful" compatriots who have moved to central Russian cities; and psychological dissatisfaction with the quality of life. These push factors are focused mainly on a lack of prospects for young people and psychological dissatisfaction. A centrifugal force sends migratory flows from the city of Pskov to other nearby but central, culturallyoriented cities of the Russian Federation. The main such cities are Moscow and Saint Petersburg.

However, there are also constraining factors for migration from Pskov. To the question "What could prevent you from leaving Pskov?" respondents gave the following answers: psychological and cultural incompatibility with the population of large cities (fast tempo of life, fierce competition, struggle for survival, cynical people); poor quality of food in shops (most respondents were accustomed to products from their farms); poor environment in large cities, no opportunities to relax in the countryside; high costs (time and money) of transportation. The psychological factor that had the strongest impact on preventing potential migrants from leaving was the stories of compatriots who came back. Re-emigration, or return migration, is spreading. Many residents of Pskov who leavet and spend time in major cities return to their ancestral homeland, thinking now that such a life was not for them. In this case, this very factor is a constraint. However, according to young people, no one can force them to stay and impose his/her way of life on them.

The ideas of respondents from a remote, depressed area were gleaned from residents of the settlement of Plyussa. This area has a large aging population, poor (neglected) infrastructure, no road transportation. The main factors pushing people from the area are social isolation, poor infrastructure, seasonal isolation, lack of road networks between settlements, difficulties in getting to a hospital, school, clinic. The employment issue for the locals, after the closure of many enterprises and schools, is the most relevant. They have lost jobs; and their standard of living has fallen because of lack of employment. The level of alcohol abuse has increased. Hence, people experience a sense of decline, stagnation, depression, and thoughts of migration. As a result, there has been a sharp increase in the migration rate and moves to other, more attractive and favorable areas of the Pskov Region. This migration from a depressed area is to the city of Pskov and other cities of the Russian Federation. We may sum up all comments about constraining factors with one sentence, "If only jobs were here, who would leave this land?" This attitude was observed in all age groups except for the old-timers and the elderly.

All groups of respondents mentioned sociopsychological and economic reasons for migration regardless of direction and destination. For all groups, a desire for a better life and psychological well-being can be accompanied with serious difficulties (Table 3). 
Table 3. Predicted problems and actual difficulties resulting from a change in residence (from Gurieva \& Kinunen, 2010, p. 79-80).

\begin{tabular}{|c|c|}
\hline Expected difficulties & Described difficulties \\
\hline $\begin{array}{l}\text { Learning a language (or, in } \\
\text { the case of a move to another } \\
\text { country, becoming immersed in } \\
\text { another culture) }\end{array}$ & $\begin{array}{l}\text { Adaptation to another language - proficiency, speech rate, } \\
\text { dialect, verbal intelligence }\end{array}$ \\
\hline Searching for a job & $\begin{array}{l}\text { Difficulty in getting a job in area of specialization; time } \\
\text { needed to search for a job; jobs are low-skilled, low-paid, } \\
\text { physically hard }\end{array}$ \\
\hline $\begin{array}{l}\text { Lacking friends, family, com- } \\
\text { munication }\end{array}$ & $\begin{array}{l}\text { Social isolation; no psychological support; no close friends, } \\
\text { family, parents; acute lack of communication; narrow circle } \\
\text { for informal communication; disturbed mental health and } \\
\text { psychological security }\end{array}$ \\
\hline $\begin{array}{l}\text { Dealing with difficulties in } \\
\text { children's adaptation }\end{array}$ & $\begin{array}{l}\text { Care of children; their lack of adaptation to a new climate, } \\
\text { environment, requirements, conditions, which can lead to } \\
\text { additional stressful situations and difficulties }\end{array}$ \\
\hline Having financial difficulties & $\begin{array}{l}\text { Limited financial potential; most of one's money spent on } \\
\text { rent, mortgage, loans, children's training, travel expenses }\end{array}$ \\
\hline $\begin{array}{l}\text { Having everyday difficulties } \\
\text { (housing, medical care, poor } \\
\text { knowledge of legal system) }\end{array}$ & $\begin{array}{l}\text { No necessary documents, no registration at place of resi- } \\
\text { dence, no insurance certificates, errors when signing agree- } \\
\text { ments, contracts }\end{array}$ \\
\hline $\begin{array}{l}\text { Having difficulties related to } \\
\text { cultural differences, mentality }\end{array}$ & $\begin{array}{l}\text { Psychological and cultural isolation, a growing sense of be- } \\
\text { ing the «foreigner,» misunderstandings with other people, } \\
\text { another culture, personality problems, dissatisfaction with } \\
\text { oneself and others }\end{array}$ \\
\hline $\begin{array}{l}\text { Having psychological problems } \\
\text { (problems in adaptation, loneli- } \\
\text { ness, nostalgia) }\end{array}$ & $\begin{array}{l}\text { Growing sense of despair, lateness, falling self-esteem, iso- } \\
\text { lation, health and mental disorders, serious psychosomatic } \\
\text { disorders }\end{array}$ \\
\hline $\begin{array}{l}\text { Dealing with negative attitude } \\
\text { of indigenous population to } \\
\text { visitors, migrants, emigrants, } \\
\text { newcomers }\end{array}$ & $\begin{array}{l}\text { Rejection of "strangers"; suspicion, lack of trust in stran- } \\
\text { gers; suspicion of involvement in all the "deadly sins," } \\
\text { crimes, infringements with no exception for cases of dis- } \\
\text { crimination and humiliation }\end{array}$ \\
\hline $\begin{array}{l}\text { Adjusting to a different climate, } \\
\text { food, water, and their quality }\end{array}$ & $\begin{array}{l}\text { Adjustment to dramatically changed nature: wind, humidi- } \\
\text { ty; changes in water, food quality, body-specific food, time } \\
\text { zone, number of sunny/nonsunny days a year }\end{array}$ \\
\hline
\end{tabular}

Migration as both the internal and the external relocation of people should be regulated, controlled, instead of being a spontaneous social phenomenon. In each area, as the survey of locals has shown, there are predictors of internal and external migration that we need to be aware of in order to anticipate and manage complex migration flows. There are three key factors in the migration patterns of Pskov Region residents: (1) unemployment, no jobs against a background of destroyed industrial infrastructure; (2) psychological dissatisfaction, depressed mood (no facilities for leisure, relaxation, family pastimes; lack of careers and prospects for the future); (3) social isolation, poorly developed infrastructure: seasonal isolation, lack of road networks, difficulties getting to hospitals, schools, clinics. 
At the same time, every area, town, settlement is a unique sociocultural, historical, and demographic unit with rich human resources and a potential for development. Knowledge of key indicators that affect both the level of migration and the attractiveness of cities and individual settlements allows us to devise a targeted scheme for managing migration flows in each case. Push factors, listed for the three places where focus groups were held, identify above all urgent problems that require an immediate response to avoid a continuing exodus. Well-timed actions will not only help regulate flows of people but also prevent a migration flow from the Pskov Region. The pull factors help to enhance the influence of psychological mechanisms to retain people. These factors may include the environment, the quality of life, the food, nature, and people with high moral values. The primary factors that may facilitate the management of this process are the time, distance, and status of a place of residence. These factors provide a basis for the development of government programs to assist or facilitate voluntary resettlement of residents from the Pskov Region.

\section{Discussion}

In general, migration is a permanent or a temporary change in place of residence; it is a continuous process depending on the interactions among four main groups of factors (Iontsev, 1999). Part of the research on migrants' motivation is based on the theory of push and pull (push/pull factors), as proposed by E. Lee. This theory can explain the main causes for migration: push factors encourage people to leave their places of origin, and pull factors are attractive to people in other regions (Lee, 1966, 47-57). Manakov and Krivulya (2012) list three main reasons for the situation in the Pskov Region today.

To identify the main causes of migration - the sociopsychological specifics of potential migrants, their expectations, motivations, and philosophy - we need systematic and comprehensive research processes, including focus groups. Our findings have allowed us to classify all the migrants and potential migrants in the Pskov Region depending on their reasons and motives for migration. For example, in the depressed and remote settlement of Plyussa, migrants seek to escape their extreme poverty and unemployment; they can be called "survival migrants." In this depressed area the category of actual and potential migrants includes all population groups, while migration itself is massive; such migration can be described as family migration because of its form. The main direction for the migration from this area is to central areas of the Pskov Region. This direction of migration flow is influenced and caused by the centrifugal force that sends people from a depressed settlement to more comfortable provincial centers and cities.

In the favorable central area, the city of Pskov, migrants seek to significantly increase their income and improve their quality of life. We can describe them as "migrants seeking new opportunities." In this relatively "favored" area, the category of actual and potential migrants includes mostly youth, students, and high school leavers, while the migration itself is selective and can be generally characterized as a youth migration. The main direction for migration is from the city of Pskov to psychologically attractive metropolitan centers and cities, where young people go in search of new opportunities, self-realization, careers, and happiness. Hence, the 
force for this migration is centripetal; it attracts youth from Pskov to larger metropolitan centers and cities.

In a border area, the town of Gdov, people living close to other countries (Estonia, Latvia) compare their financial situation and opportunities with those of people living in nearby countries. Migrants from this area tend to move in order to avoid an environmental crisis or progressive degradation of the environment, structural unemployment, and poor economic opportunities. We can call these people "migrants in search of hope and prosperity." Their focus is on another place, where they will live better. There is no doubt that the main factor in migration from this town is the closeness (psychological and physical) of foreign countries with more comfortable living conditions. We can describe the direction for this migration as over the border, understood both broadly and narrowly. A broad understanding suggests migration to another country. A narrow understanding suggests a move to a more comfortable living environment. Actual and potential migrants from this area include males of working age and females of childbearing age.

Based on the findings, we can conclude that strengthening the role of factors preventing migration through improvements to social infrastructure, transportation, and remote settlements in the Pskov Region will allow us to get away from a stereotypical idea of the area as one of the disadvantaged regions of Russia. An important resource in need of being used intensively for socioeconomic development in the region is climatic and natural conditions.

In general, a significant way to make the Strategy for Socioeconomic Development of the Pskov Region through 2020 dynamic in meeting target indicators lies in carefully and rationally using the human potential of the region, its climate and natural environment. To consider this issue, one needs systematic and scheduled measures to control and constrain the migration outflow. Interested parties among the residents, especially potential migrants, should share psychological problems and social difficulties that accompany the process of migration.

\section{Conclusion}

Labor (economic) migration is a typical kind of migration. It involves the resettlement of people for the purpose of finding employment with proper remuneration. Migration can have other causes, such as a desire to change sociocultural, housing, environmental, natural, climatic, and other conditions. But without improvement in the economic and social sphere, improvement of these other factors will be able to prevent the migration only of elderly or incapacitated people. To retain the younger generation, it is necessary to inform people of all the difficulties that potential migrants may face and to make systematic and large-scale efforts to develop the region, to improve its image (thereby encouraging the residents to be proud of and to cherish its heritage and achievements), and to create a comfortable environment. Comprehensive implementation of the Strategy in a socially responsible way will allow achieving a new level of management in which the needs of the population and the quality of life of an individual will be coordinated with objectives set by executive authorities in charge of regional development.

In the Pskov Region, there is an opportunity to predict and classify with high accuracy the direction of migration processes in three different areas: depressed, 
border, and center. Our research has shown that, depending on where they live, potential migrants are at different places in the migration process. In the depressed and remote Plyussa settlement, migrants seek to escape their extreme poverty and unemployment. In the city of Pskov, in the "favorable" central area, migrants seek to increase their income level and improve their quality of life. In the town of Gdov, a border area, people living close to other countries (Estonia, Latvia) compare their financial situation and opportunities with those of their foreign neighbors. Potential migrants from border areas tend to move because they want avoid an environmental crisis or progressive degradation of the environment, structural unemployment, and poor economic opportunities.

It begins to be possible to answer the main question regarding the expediency and necessity of the migration process in one of the Russian regions, Pskov. Actual, but currently unsolved, problems are being presented to social psychologists: Which factors are the most significant for migration - pull or push? Which methods of social-psychological correction need to be developed to adequately prepare potential migrants to move to another place to live, including a foreign country?

This study constitutes the first attempt to determine and explain the main reasons for migration in three territorial segments of the Pskov Region. The territorial division of the Pskov Region was determined after consideration of cultural, psychological, and economic aspects. The necessity of studying the main reasons for migration as indicators of the sociopolitical and psychological stability of the region in the future was pointed out.

\section{References}

Belinskaya, E. P., \& Stefanenko, T. G. (2000). Etnicheskaya identichnost [Ethnic identity: Concept, formation, measurement models]. In D.I. Feldshtein (Ed.). Etnicheskaya sotsializatsiya podrostkov [Ethnic socialization of teenagers] (pp. 75-107). Moscow: Moscow Psychological and Social Institute; Voronezh: MODEK.

Berger, P. L., \& Luckmann, T. (1966). The social construction of reality. Garden City, NY: Anchor Books.

Berry, J.W. (Ed.). (2003). Cross-cultural psychology: Research and applications (2nd ed). Cambridge, UK: Cambridge University Press.

Evdokimov, S. I. (2010). Migratsiy naseleniy kak otrazhenie ekonomicheskoy privlekatelnosti regiona [Migration as reflection of economic attractiveness of region (as exemplified by the Pskov region)]. Vestnik Rossiyskogo gosudarstvennogo uversiteta imeni Kanta [Bulletin of the I. Kant Russian State University], 1, 108-112.

Gurieva, S. D., \& Kinunen, T. A. (2006). Sotsialno-psichologicheskie osobennosti v migatsionnom povedenii na primere ingermaladskix finnof [Socio-psychological specifics in migration behaviour (as exemplified by the Ingrian Finns)]. Voprosy psichologii [Issues in Psychology], 6, 97-105.

Gurieva, S. D., \& Kinunen, T. A. (2010). Akulturatsiya kak krizis identichnosti [Acculturation as identity crisis]. Vestnik Sankt Peterburgskogo universiteta. Seriya 12 [Bulletin of Saint Petersburg State University. Series 12], 1, 74-82.

Hrustaleva, N. S. (1996). Psichologiy emigrakhii [Emigration psychology (socio-psychological and personal issues)]. (Unpublished doctoral thesis). Saint Petersburg: Saint Petersburg State University.

Hutnik, N. \& Barrett, M. (2003). Ethnic minority identity: Twenty years on. Poster presented at the 11th European Conference on Developmental Psychology, Milan, Italy, August 2003. 
Iontsev, V. A. (1999). Mezhdunarodnaya migratsiya naseleniya [International migration: theory and history of research]. Moscow: Dialog-MGU.

Jasinskaja-Lahti, I. (2000). Psychological acculturation and adaptation among Russian-speaking immigrant adolescents in Finland. Helsinki: Helsingin yliopiston verkkojulkaisut.

Jasinskaja-Lahti, I., \& Liebkind, K. (2000). Acculturation and Psychological Well-Being Among Immigrant Adolescents in Finland: A Comparative Study of Adolescents From Different Cultural Backgrounds. Journal of Adolescent Research, 15(4), 446-469. doi: 10.1177/0743558400154002

Lebedeva, N. M. (2001). Khenostno-motivatsionnay struktura lichosti v russkoy culture [Valuemotivational personality structure in Russian Culture]. Psichologicheskiy zhurnal [Psychological Journal], 22(3), 26-36.

Lee S.-K., Sobal, J., \& Frongillo, E. (2003). Comparison of Models of Acculturation. The case of Korean Americans. Journal of Cross-Cultural Psychology, 34(3), 282-296. doi: 10.2307/2060063

Lee, E. (1966). A theory of migration. Demography, 3, 47-57.

Liebkind, K. (2001). Acculturation. In R. Brown \& S. Gaertner (Eds.), Blackwell handbook of social psychology: Intergroup processes. (pp. 386-406). Oxford, UK: Blackwell.

Manakov, A. G., \& Krivulya, I. V. (2012). Demograficheskay obstanovka v Pskovskoy oblasti [Demographic situation in the Pskov Region in 2010 and the first half of 2012]. Pskovskiy regionologicheskiy zhurnal [Pskov Regionological Journal], 15, 76-82.

Mirsky, J. (2001). A pre-immigration group intervention with adolescents: An evaluation study. Journal of Social Work Research and Evaluation, 2(2), 307-318.

Pavlenko, V.N. (2001). Akkulturatsionnye strategii I modeli trasformatii identichnosti migrantov [Acculturation strategies and model to transformidentity among migrants]. In G.U. Soldatova (Ed.), Psichologiya bezhentsev i vynuzhdennyx pereselentsev [Psychology of refugees and internally displaced persons: Experience of research and practice] (pp. 25-40). Moscow: Smysl.

Ravenstein, E. G. (1985). The laws of migration. Journal of the Royal Statistical Society, 48, 167-227.

Region Rossi [Regions of Russia]. (2013). Statisticheskiy sbornik [Statistical Compendium]. Moscow: Rosstat.

Schwartz, S.H., \& Prince-Gibson, E. (1998). Value priorities and gender. Social Psychology Quarterly, 61(1), 49-67. doi: 10.2307/2787057

Soldatova, G. U. (2002). (Ed.). Psikhologicheskaya pomosh' migrantam: travma, smena kultury, krizis identichnosty [Psychological support of the migrants: Trauma, change of the culture, crisis of identity]. Smysl: Moscow.

Stefanenko, T. G. (1999). Etnicheskiya psichologiya [Ethno Psychology]. Moscow: Institute of Psychology RAS.

Tartakovsky, E. A. (2007). Longitudinal study of acculturative stress and homesickness: highschool adolescents immigrating from Russia and Ukraine to Israel without parents. Social Psychiatry and Psychiatric Epidemiology, 42(6), 485-494. doi: 10.1007/s00127-007-0184-1

Zakharov,V. Y., Voronin, G. L., \& Zakharov, I. V. (2014). Sotsialnye problemy transformatii promyshlennyx predpriytiy [Social problems of transformations to industrial enterprises]. Sotsiologicheskie issledovaniya [ Sociological Research], 2, 25-36.

Zilber, N. \& Lerner, Y. (1996). Psychological distress among recent immigrants from the former soviet union to Israel: I correlates of level of distress. Psychological Medicine, 26(3), 493-501. 